\title{
The Effectiveness of Teaching Vocabulary by Using Cartoon Film toward Vocabulary Mastery of EFL Students
}

\author{
Fathul Munir \\ IAIN Tulungagung, East Java, Indonesia \\ Email: fathulmunir985@yahoo.co.id
}

\begin{abstract}
This article investigates the suitable media to develop students' vocabulary in elementary level is audio visual media especially cartoon film media, the problems of the study are: (1) How is the students' score before using cartoon film media? (2) How is the students' score after using cartoon film media? (3) How is the effectiveness of using cartoon film media on the students' vocabulary mastery? This research conducts experimental design; it is pre-experimental design in the form of one-group pre-test and post-test. The instruments were used are pre-test, treatment, and the post-test. The analysis technique of data analysis used t-test statistical analysis. The use of cartoon film media will be significant if $t_{\text {count }}>t_{\text {table. }}$ Data analysis shows that $t_{\text {count }}>t_{\text {table }}(5,20>1,71)$, so $H_{0}$ is rejected or $\mathrm{Ha}$ is accepted. Based on the research finding, the researchers conclude that (1) the students' mastery on vocabulary before being taught by using cartoon film media can be seen from the result of pre-test, there are 15 students get excellent result, there are 2 students get good result, there are 4 students get enough result, there are 3 students get less result and 1 student get low result. It means that there are 32\% students who get low score. (2) The students' mastery on vocabulary after being taught by using cartoon film media can be seen from the result of post - test, there are 19 students get excellent result, there are 5 students get good result and there is 1 student get enough
\end{abstract}


result. (3) The significant different, between students' mastery on vocabulary before and after taught by using cartoon film media can be seen from the result of pre - test, it showed that 15 students who get score 80 - 100 where as the result of post - test showed that 19 students who got score $80-100$. It means that the result of this research showed that $t_{\text {count }}>t$ table $(5,20>1,71)$. It indicates that cartoon film is suitable to teach vocabulary. So from the result the researchers suggest to the English teacher that cartoon film is effective to teach vocabulary for young learners.

Keywords: effectiveness, teaching, vocabulary mastery, cartoon film

\section{INTRODUCTION}

English is one of international languages, it means that English is learnt by many countries in the world, many people have used English for international communication and it is used as a key of knowledge, science and technology. So, English is very important to conduct communication everywhere, every time, and everything.

English language consists of four skills: listening, speaking, reading and writing. Vocabulary is one component of those skills. One cannot express his idea if the lacks of vocabulary. Vocabulary is important for the students to support their four language skills (David, 1991:9). It means that if the students master vocabulary, it will make the students easier to learn English language.

Vocabulary is a unique to a content area as unique as fingerprints to a human being. Teachers know they must do something with the language of their content areas, but they often have trouble with what they should do. Consequently, they reduce instruction to routines that have withstood time and teacher centered practice, directing students to look up, define, memorize and use content specific words in sentences. Content area vocabulary must be taught well enough to remove potential barriers to students understanding of texts as well as to promote a long-term acquisition of the language of a content area. The organizing principle underscores the main premise of the chapter: teaching words well means giving students multiple opportunities to learn how words are conceptually related to one another in the material they are studying (Richard, 1999:314). In other words, vocabulary must be taught to the students in certain period to make them understand the text.

Vocabulary is taught in elementary level; in fact the students master simple vocabularies like animal, clothes, things in the classroom etc. They only have little vocabulary, it is caused by they do not have spirit to learn new vocabularies and the teacher rarely uses a suitable media to teach vocabulary. It will generate the students to have spirit to read the book. Then they will master English vocabularies. 
Many people are difficult to master vocabulary because of the using of different techniques between English and Indonesia. The English people everyday use English language to speak others but in Indonesia most of the learners speak English language in certain condition. So, Indonesian students' vocabulary is still poor. If everyone has motto "Book is the world's window" because they like to read in order to enlarge and improve their knowledge.

The students got many vocabularies by conducting reading activity. That motivation gives task and practice by involving reading activity in order that the student can understand word by word and meaning of words. So that, they can learn vocabulary. Most of students begin to read something because they have seen and they have heard something that is pronounced by other people. Using of media is needed to conduct teaching and learning process in the class. The suitable media is audio visual media because the media contains picture and voice so the students can see and hear directly such as cartoon film. By using this media, the students will be enjoyable and pleasure to learn English vocabulary, make the message clearly, can save the teacher energy, can motivate the student to learn, can increase the quantity of teaching and learning.

Vocabulary is very important in learning English because by having many vocabularies someone can be easier to learn English. It is different when someone has limited vocabulary, they could not learn English better. For example if they have many vocabularies they will be easier to look for the information from English magazine or English newspaper and vice versa. It is better for students to use media in learning vocabulary, in order to make them easier in learning English. Media is medium to send message from speaker to receiver. It means that the media can help the teacher to send their information for their students. The examples of media are television, LCD projector, radio etc.

From the statement above this study focuses on choosing a suitable media that is audio visual media to teach vocabulary, in this case cartoon film is considered as suitable media. By using cartoon film the students seem easier to understand the vocabulary because they like the cartoon especially Dora's cartoon. So, the students feel easy to follow the story and understand word by word in Dora's film. Children like cartoon, so that they will enjoy teaching and learning in the classroom if a teacher uses cartoon. For the children, cartoon is fun. Putranti \& Mina (2015) state that cartoon film offers a fun and meaningful teaching and learning experience.

A meaningful teaching comes from the ability of the teacher to choose the best and appropriate teaching method to be used in the classroom. A teacher should inspires the students in his/her class by implementing the interesting teaching strategies in his/her class. Iftanti (2015:1) states that an inspiring English lecturer is the one who could implement the teaching technique strategies and skills which is changing students' learning style. 


\section{LITERATURE REVIEW}

\subsection{The Nature Vocabulary}

Vocabulary is one of the most obvious components of language and one of the first things applied linguists turned their attention to. Vocabulary is list of words with their meanings, especially in a book for learning a foreign language (Richard, 2002:4). According to Nunan (1991:101) Vocabulary is more than lists of target language word. Based on the definition above it can conclude that vocabulary is intimately interrelated in grammar. In fact, it is possible to divide the lexical system of most language into grammatical word.

Teachers know they must do something with the language of their content areas and provides much of the basis for how well learners speak, listen, read and write. It is also stated that "vocabulary is the total of words in a language". Vocabulary includes of words that are used in communication through language, whether using language in the manner of spoken or written (Djiwandono, 1996:42). It can be inferred that vocabulary is the total of words in a language.

Advanced learners can generally communicate well, having learnt all the basic structure of the language. However, they need to broaden their vocabulary to express themselves more clearly and appropriately in a wide range of situations. The students might even have receptive knowledge of wider range of vocabulary, which means they can recognize the item and recognize its meaning. Nevertheless, their productive use of a wide range of vocabulary is normally limited and this is one of the areas that greater attention.

Vocabulary study seems consistently to revolve around the dull routines of looking up defining and memorizing words and using them in sentences. Although there was nothing inherently wrong with looking up, defining and memorizing words and using them in sentences, the approach itself is too narrow for users to learn words in depth. Instead, learners memorize definitions to pass the Friday quiz and forgot them on Saturday.

Having students learn lists of words is based on the ill-founded conclusion that the acquisition of vocabulary is separated from the development of ideas and concepts in a content area. Teaching vocabulary often means assigning a corpus of words rather than exploring words meanings and relationships that contribute the student's conceptual awareness and understanding of a subject. Once teacher's clarity the relationship between words and concepts, they are receptive to instructional alternatives.

One classification involves the three types of reading vocabulary found in textbooks (Richard, 1999:314);

a. The first type general vocabulary, it consists of everyday words with widely acknowledge meanings in common usage.

b. The second type, special vocabulary, it is made of words from everyday vocabulary that take on specialized meanings in a particular content area.

c. The third type, technical vocabulary, it consists of words that are used only in a particular area. 
According to Harmer, there are two kinds of vocabulary (Harmer, 1991:159):

\section{a. Active vocabulary}

Active vocabulary is used in oral and written expression by the students. The words that the students understand well enough they use the words effectively in both speaking and writing.

b. Passive vocabulary

Passive vocabulary is deals with words the students will recognize understand in a context that helps them recall the word meaning. The students usually apply passive vocabulary in listening and reading materials.

From the explanation above, the types of vocabulary can be classified into two these are active and passive vocabulary. Active vocabulary used in speaking and writing skills. Then passive vocabulary used in listening and reading skills.

a) Kinds of Vocabulary Topics for Elementary School

According to Redman (2002:2) there are some topics for intermediate level are as follows :

1. The world around the learner

This topic is divided become five sub topics, among other things:

a. The physical world

Example: oceans, mountains, deserts, hurricane and so on

b. Weather

Example: showers, cloudy, fog, pour with rain and so on.

c. Using the land

Example: plants, agriculture, mining, holticulture, ground for ricegrowing, etcetera.

d. Animals and insects

Example: lion, wild, spider, rabbit, etcetera.

e. Countries, nationalities and language

Example: Sweden, Swiss, Arabic and so on.

From the description above, it can be concluded that the young learners study simple vocabulary in their environment in order that the students know about the environment.

2. People as follows:

He further mentions that this topic is divided into six sub-topics, they are

a. The body and what it does

Example: bend your knees, bite your nails, and so on.

b. Describing people's appearance

Example: tall and blond with broad shoulders.

c. Describing Character

Example: shy, friendly, unpleasant, and so on.

d. Human feelings and actions 
Example: pride, jealous (of), stare, whisper, and so on.

e. Family and friends

Example: niece, relatives, surname, best friend, and so on.

f. Ages and stages

Example: teenagers, grow up, adult, pregnant, and so on.

3. Daily life

This topic is divided become 15 sub-topic, they are:

a. Daily routines

Example: get up, leave home, go to sleep, etcetera.

b. Homes and buildings

Example: flat, on the ground floor, roof, and so on.

c. Around the home 1

Example: lounge, on the sofa, food mixer, and so on.

d. Around the home 2

Example: washbasin, tidy, polish, etcetera.

e. Everyday problems

Example: it is not working, drop, break, and so on.

f. Money

Example: coins, borrow, I cannot afford it etcetera.

g. Health: illness and disease

Example: flu, sore throat, sneezing, etcetera.

h. Health: injuries

Example: twist my ankle, bleeding, bruise, and so on.

i. Clothes

Example: shirt, get dressed and so on.

j. Shops and shopping

Example: chemist, shop assistant, I am being served and so on.

k. Food

Example: carrot, peach, and so on.

1. Cooking and restaurants

Example: fry, salty, main course, book a table and so on.

m. Town and country

Example: suburbs, noisy, fields and so on.

n. On the road

Example: turn left, traffic lights, accident and so on.

o. Transport

Example: coach, bus stop, platform, get off and so on.

4. Communication and technology

This topic is divided into four sub-topic, they are:

a. Newspapers

Example: journalist, headline, article and so on. 


\section{b. Television}

Example: programmer turns on, soap opera, and so on.

c. On the phone

Example: engaged, operator, save, and so on.

d. Computers

Example: screen, software, save, data, and so on.

From the description above, it is known that the example theme or topics in teaching vocabulary in elementary level, such as animal, people, daily activity, computers and technology and so on. From each topic the students must remember because it makes the students easy in learning English.

\subsection{Teaching Vocabulary}

Teaching is an activity or process of transforming knowledge to help someone require changes and develops their skills, attitudes, ideas and appreciations. They are influenced by affective, cognitive and psychomotor domains. In the past, vocabulary teaching and learning were often given little priority in second language programs, but recently there has been a renewed interest in the nature of vocabulary and its role in learning and teaching (Richard:255).

Traditionally, the teaching of vocabulary above elementary levels was mostly incidental, limited to presenting new items as they appeared in reading or sometimes listening texts. This indirect teaching of vocabulary assumes that vocabulary expansion will happen through the practice of oer language skills, which has been proved not enough to ensure vocabulary expansion. Nowadays, it is widely accepted that vocabulary teaching should be part of the syllabus, and taught in a well-planned and regular basis. The vocabulary is the center of language teaching because the language consists of grammatical lexis, not lexicalized grammar.

There are several aspects of lexis that need to be taken into account when teaching vocabulary. The list below is based on the work of Gains and Redman (1986).

a. Boundaries between conceptual meaning: knowing not only what lexis refers to, but also where the boundaries are that separate it from words of related meaning (example: cup, mug, bowl).

b. Polysemy: distinguishing between the various meaning of a single word from with several and closely related meanings (head: of a person, of pin, of an organization).

c. Homonymy: distinguishing between the various meaning of a single word form which has several meanings which are not closely related (example, a file: used to put papers in or a tool)

d. Homophony: understanding words that have the same pronunciation but different spellings and meanings (example: flour, flower). 
e. Synonymy: distinguishing between the different shades of meaning that synonymous words have (example: extend, increase, and expand).

f. Affective meaning: distinguishing between the attitudinal and emotional factors (denotation and connotation), which depend on the speakers attitude or the situation social-cultural associations of lexical items is another important factor.

g. Style register, dialect: being able to distinguish between different levels of formality, the effect context and topics, as well as differences in geographical variation.

h. Translation: awareness of certain differences and similarities between the native and the foreign language (example: false cognates).

i. Chunks of language: multi-word verbs, idioms, strong and weak collocation, lexical phrases.

j. Grammar of vocabulary: learning the rules that enable students to build up different forms of the word or even different words from that word (example: sleep, slept, sleeping, able, unable, disability).

k. Pronunciation: ability to recognize and reproduce items in speech. In other word the students try to pronounce the word better.

It can be said that there are fourteen aspects that must be known and understood by the teacher in teaching vocabulary in the class. So when the teacher explains the vocabulary the teacher also must explain that aspects to the students, in order that the students know the aspects well.

\subsection{Methods in Teaching Vocabulary}

A method is theoretically related to an approach, organized by the design, and practically realized in procedure. Method is the plan of language teaching which is consistent with the theories. In other words, method is procedural (Setiyadi, 2006:8). Heinich also states that there are the general categories of methods in teaching English vocabulary are as follows (1993:16):

a. Presentation

In the presentation method, a source tells, dramatizes, or otherwise discarnate in formation to learners. It is a one-way communication controlled by the source, with no immediate response.

b. Demonstration

In this method of instruction, learners view a real or lifelike. Demonstrations may be recorded and played back by means of media such as video

c. Discussion

As a method, discussion involves the exchange of ideas and opinions among students or among students and teacher. It can be used in small or large groups. 
d. Drill and practice

In drill and practice learners are led through a series of practice exercises designed to increase fluency in a new skill or to refresh an existing one. To be effective, the drill and practice exercises should include feed-back to reinforce correct responses and to remediate errors learners might make along the way.

e. Tutorial

Tutorial is most often done one on one and is frequently used to teach basic skills, such as reading and arithmetic.

f. Cooperative learning

Critics of competitive learning urge instead an emphasis on cooperative learning as an instructional method. They argue that learners need to develop skills in working and learning together because their eventual workplaces will require teamwork.

g. Gaming

Gaming provides a playful environment in which learners follow prescribed rules as they strive to attain a challenging goal. Games can be a way for students to be active learners.

h. Stimulation

Stimulation involved learners confronting a scaled-down version of a reallife situation. The simulation may involve participant dialog, manipulation of materials and equipment, or interaction with a computer.

i. Discovery

The discovery method uses an inductive or inquiry approach learning, it presents problems to be solved through trial and error.

j. Problem solving

Lifelike problems can provide the starting point for learning. In the process of grappling with real-world challenges, the students can acquire the knowledge and skills needed in the real world after graduation.

From the statements above there are some methods in teaching vocabulary, such as game, practice and drill; discussion etc. Each methods has a strength and the weakness. So the teacher must choose the suitable method that is similar with the students' characteristics.

\subsection{The Characteristics of the Elementary School Learners}

The characteristic of young learners are, junior achievement of Michiana (2010) are as follows:

1) 5 years (Kindergarten)

At this level, children begin to combine simple ideas into more complex relationships. As a result, they need an environment rich in printed materials that stimulate the development of language and literacy skills. They also need a variety of direct experiences to develop cognitively, physically, emotionally, and socially. 
2) 6 years ( $1^{\text {st }}$ grade student)

First-graders are active learners and demonstrate considerable verbal skills. They love games and rules, developing concepts and problem-solving skills from these experiences. Hands-on activity and experimentation are important.

3) 7 years ( $2^{\text {nd }}$ grade students)

As seasoned veterans of two years of schooling, second-graders are increasingly able to reason, listen to others, and show social give-and-take. They can display flexibility, open-mindedness, and tolerance of unfamiliar ideas to a remarkable extent.

4) 8 years ( $3^{\text {rd }}$ grade students)

Third graders combine great curiosity with increased social interest. They are able to learn about people who live elsewhere in the world, but their understanding of what they read is dependent upon relating ideas to their own experience.

5) 9 years ( $4^{\text {th }}$ grade students)

Fourth graders are somewhat self-conscious and prefer group activities to working alone. They also are beginning to understand abstractions as well as cause-and-effect relationships, but need real experiences in social settings. In this level the students still like to play with their friends when the teacher explains the material. They always imagine the abstract things in their lives. They also know the effect of what they do, so they can differentiate the good and bad action.

6) 10 years $\left(5^{\text {th }}\right.$ grade students $)$

Fifth graders may be experiencing bodily changes and rapid growth spurts, which cause periods of frustration and anger. They generally are interested in and enthusiastic about places and problems in the news and want to know what caused these problems, where they occurred, and the reasons for them.

7) 11 years $\left(6^{\text {th }}\right.$ grade students)

Sixth graders are in a period of transition between childhood and adolescence. As the result, they tend to be sociable and need opportunities to express feelings and opinions. They do not have the ability to view issues from the perspective of a whole society, but need to encounter analytical questions about their economic society and history.

In the explanation above, the characteristics of elementary school learners from the fifth years until the eleven years is not the same. So the teacher must understand it well in order to conduct teaching and learning process successfully.

\subsection{Media}

\section{The Definition of Media}

According to Heinich in (Daryanto, 2010:4) Media is an intermediary or introductory between a speakers to the listener in the communication. So the media as a connector between communicator and communicant. 
Media is a means of communication and source of information Smaldino (2002:9). From the definition above it can be said that anything which carries the information between a source and a receiver is called media. The purpose of media is to facilitate communication and learning (Heinich, 2002:9).

\section{Kinds of Media}

According to Djamarah and Zain (2010:124), there are 3 kinds of media:

1. Audio media: Audio media is media that only show the sound such as radio cassette recorder etc. So this media is not suitable for the deaf students.

2. Visual media: Visual media is media that only show a picture without a sound. It means that the students just see a picture without hearing the actor says. The example of this media is strip, slides photo etc.

3. Audio visual media

Audiovisual media is the media which show a picture and sound. This media is the better media than the other media. This media is divided into:

k. Quite audiovisual: media that show a sound and quite picture. Ex sound slides.

1. Movement audiovisual: this media show the sound and the picture than can move. Example: cartoon film.

m. Pure audiovisual: both of sound and picture are from one source. Example: film, video cassette.

n. Not pure audiovisual: both sound and picture come from another source. For example the picture from LCD projector and the sound come from active speaker.

\section{Cartoon Film}

Cartoon film is the same as animation film. The word animation was derived from Yunani "anima" which the meaning is soul and live. The word animation also has a mean is to give a live for the object by stiring the object in the specific time. From the statement above it can concluded that animation is a group of picture or object (Wordpress: 2010)

It means that cartoon film is animation films that show a 2 dimension film. So the cartoon film is a picture that can move and make a sound.

1) The characteristics of cartoon film

In teaching and learning vocabulary, cartoon film has some characteristics. There are as follows:

A. The duration of cartoon film is short

B. The easy vocabulary, it means that it can be used in daily communication.

C. The intonation of speaker is calm and fluent.

D. It has moral values. 
At school, a teacher considered as a teacher and educator has the role and function strategies in instilling knowledge and morals / manners for students. There is a hope, and may demand on the students that they will be the knowledgeable men (clever, diligent); on the other hand the more severe is that the students will be a human noble character and morality (akhlakul kharimah). If human beings are just smart without having a certain character might later as an adult, she or he would be the villain of the people, corrupt (Widodo, 2005).

In many ways, methods and strategies implemented to educate students to be a noble human being. If students are just merely lectured every day, they would be bored, and possibly immune. So, from the case above cartoons film is suitable media in teaching vocabulary for young learner. By using media cartoon film is expected to be PAKEM learning process, more challenging and more meaningful.

Each cartoon film making and entertainment elements in addition to promoting a business, there is a moral message insertion of its creator. There are obvious, some are subtle. There is a high-value levels there are only a little. The moral messages contained in the cartoons in Indonesia, among others: honesty, helpfulness, assertiveness, confidence, never give up, courtesy, chivalry, etc.. We cannot avoid the negative elements of the cartoon (ie the existence of evil characters) but at least try to minimize and neutralize the situation with a logical explanation of the principle of balance.

As the term of Ying and Yang, there are no bad either. Two things cannot be separated pliers. Some examples are frequently watched cartoons and kids love to educate and contains elements of character, for example: Sponge Bob (friendship), Dora the Explorer (adventure), Scooby Doo (eradication of evil), Avatar the Legend (struggle and heroism), Kung Fu Panda and others.

\section{Classifications of media}

According to Allen (in Daryanto, 2010:17) the purpose and characteristics media are as follows:

a) Silent visual media, example; newspaper, magazine etc.

b) Film, that is, a 3D animation or others.

c) Television, it is audiovisual media.

d) 3 dimension object. It's like cartoon film

e) Record

f) The lesson

g) Demonstration

h) Text book, it is the same as hand book or guidance book.

i) Oral

Based on the description above, it makes the teacher and other instructors to choose the suitable media in order to teach the purpose of teaching and learning. 
1. Function of Audiovisual media

The function of audio visual media according to Levie and Lents (Arsyad, 2001:17):

a) Attentive function: Interest and build a student concentration to the lesson. By using audio visual in learning process, students' spirit increasing while they listen the explanation and they become more concentrate on the lesson.

b) Affective function: In this affective function the students feel enjoyable in reading picture text.

c) Cognitive function: It shows a visual or picture that makes the students easier to understand and remember the information. It means that by using the visual and the audio make the information clear and the students easy to understand it.

d) Compensatory function: It helps the lower level students to understand the information by showing another text.

From the description above, there are four functions of media such as attentive function, affective function, cognitive function and compensatory function. Those functions can be used to teaching English vocabulary.

According to Daryanto (2010:5) there are some functions of media. There are as follows:

a. Make clear the message: It means that by using media the information from teacher is clearer. So the media can help the teacher in transferring knowledge to the students.

b. It can save the teacher energy: It means that by using media the teachers just need little energy because there is some media which help the teacher in teaching process. So the teachers only add a little explanation about the lesson.

c. It can motivate the students to learn: It means that by see the picture in the media the students more motivated. In other words if the teacher uses media the students more focuses on the picture and they will try to understand what the actor said.

d. It can increase the quantity of teaching and learning. It means that by using media in teaching process it makes the quantity of teaching process increases.

\section{Characteristics of Media}

According to Gerlach and Ely in (Arsyad,1997:12) there are three characteristics of media are follows :

1. Fixative property

This characteristic shows skill of media to record, save take care and construction the event or object. The event or object can be photography, video tape, audio tape, disc computer, and film. 
2. Manipulative property

Transformation of the event or object makes possible because this media have manipulative characteristics. This object is showed to students for two or three minutes by taking picture technique time-lapse recording.

\section{Distributive property}

Distributive property of media can be object or event that be transformated by space and the way of equivalent from this event is offered to all of students to stimulate their experience has same relative connected that event.

From those explanations above, it can be said that those properties must be included as the characteristics of media.

The characteristics associated with educational media are as follows:

1. It gives information deeply, widely and It establish and convey the messages to the learners.

2. By using media it will create variety in teaching.

3. It teaches the teachers use this media directly.

4. It provides pattern of study to the local communities and invite the community participation.

5. It increases the variety of learning opportunities and resources.

6. It makes learning process interesting.

7. It restructures the material, process and participants' attitudes.

8. It is more effective than the use of traditional technique.

It means that the media bring many advantages to be used in teaching English vocabulary.

According to Daryanto (2010:53) the characteristics of multimedia in teaching and learning process are as follows:

1. It has more than one convergent media for example it combines two elements audio media and visual media.

2. Interactive. It means that the media are used to be able to communicate among the users.

3. The media give easiness to the user. So, the users can use it without guidance from other people.

From the description above, it is known that the multimedia has some characteristics which bring some advantages when the teacher uses it in teaching and learning process.

\subsection{Previous Studies}

Nurhayati's study (2008:126) indicates that the frequency of conducting various game could make the students more enjoyable to study English especially reducing their burden to join activities. The students were very energetic and they needed some activities that could make them move. It implies that teachers need to be creative in creating the activities for the students, so that the students do not get bored easily. Besides the strengths, the weaknesses that 
were found in the research such as limited time, the students' ability and motivation, the condition of the teacher who paid more attention to the administrative tasks should be considered to be able to a better teaching-learning process apply the better techniques in order to get the perfect result in improving the students' English vocabulary, spelling and grammar.

Moreover, the up to date research of using interesting media to inspire reading comprehension conducted by Nurhayati (2014b) investigated retelling the ideas and summarizing text using interesting picture series can increase the students' motivation in reading class especially to improve their reading comprehension. They got more strategies to deliver their ideas to other friends after participating in creating picture series and using those reading strategies. It is also supported by Nurhayati's current research (2015a) investigated improving students 'pronunciation ability through Go Fish and Maze Game; moreover it also conducted to get more information what activities which make them tend to become more confidence to pronounce some basic words in enjoyable situation.

\section{RESEARCH METHOD}

The research design used in this study is pre-experimental design in the form of one-group pre-test and post-test. Experimental research is a scientific investigation in which an investigator manipulates and controls one or more independent variables and observes the dependent variable (Ary, 1985:284). It means that the experimental research needs a group that can be a control group and other group is experimental group. Experimental research can be done in the laboratory, in the class and in the field.

According to Ary (2006), an experiment is as scientific investigation in which the research manipulates one or more independent variable, controls any other relevant variable, and observes the effect of manipulations on the dependent variable(s).

Table 1.The test illustration of one group pre-test and post-test (Suryabrata, 2010:100)

\begin{tabular}{|l|l|l|}
\hline Pre-test & Independent Variable & Post-test \\
\hline $\mathrm{Y}_{1}$ & $\mathrm{X}$ & $\mathrm{Y}_{2}$ \\
\hline
\end{tabular}

In this study the experimental study was done to the fourth grade students at MI Al Hidayah 02 Betak as population. It is done in order to know the significance of Cartoon film media in teaching vocabulary. Sample is also as a way the researcher selects number of individuals as a sample which represents the population. In this study, the researchers took the populations that are the entire of fourth grade students. Then the fourth grade as a sample consists of 25 students at MI Al Hidayah 02 Betak because this study has not been implemented yet in this school especially about media in teaching vocabulary. 
By applying this technique the students' knowledge increases than before and it also got experience to conduct useful experimental research. This study uses primary data because it conducted pre- test and post-test to get the data.

The procedures were as follows:

1. Pre-Treatment

Before giving treatment by using audio visual as media in teaching and learning, the researchers give pre-test. On the result of pre-test, the researchers found that the fourth grade students' result pre-test was poor. The reason is because the teacher never tries to teach vocabulary by using audio visual media such as cartoon film. The English teachers in MI Al Hidayah 02 Betak teaches the students only use students' worksheet withouth color and it makes the students difficult to memorize about vocabulary like animals, food, beach, and color.

\section{Treatment}

The treatment in this research is audio visual media especially cartoon film, the researchers taught vocabulary by using audio visual as a media of teaching. The material animals, clothes, and beach are used to teach vocabulary, in order to increase their vocabulary mastery. Audio visual media help the students easier to memorize vocabulary. The students can see and hear by using audio visual media especially video disc (film) with instruction for teacher. It makes the students were enthusiasm, enjoyable and interested in learning English. When teaching and learning process were conducted by using audio visual media especially (cartoon film) is done, the students were very happy and they got new spirit to learn English.

\section{Post Treatment}

After doing treatment, it is given posttest to all students. Posttest is used to know the students vocabulary mastery after teaching by using audio visual media especially cartoon film; how far the students understand and remember about some vocabulary that given after giving treatment process is done. Apparently, the result of the test showed that the students' vocabulary mastery improved significantly, because their scores after giving treatment is higher than before.The last, after the class has been exposed to the treatment for some period of time, the administering test of the dependent variable (or otherwise measures it). After reducing, classifying, analyzing the data, and then determining whether there is/are any significant different between before using cartoon film and after using cartoon film as media, it is determined whether the treatment made the different or not.

The instruments used by the researchers are as follows:

a) Pre-Test

Before teaching the new material by using cartoon film media as media or without using it, a test is given to the students by taking the previously material. A test is a means of measuring a knowledge skill, feeling, intelligence of an 
individual of group. Test produced numerical score that can be used to identify, classify, or evaluate test takers. There are two tests, pre-test and post-test. Pretest was given to the experimental group and control group by conducting some tests, in other word, it is used to know the ability to the students. The score obtained were analyzed to determine between pre-test and post-test. The respondents were asked to do the twenty five questions of vocabulary. Time allocation of test is 60 minutes. This kinds of test is ten multiple choices, ten questions to arrange the sentence in good order, five items as matching the picture.

b) Treatments

The treatments here mean instruction media refers to cartoon film "Dora's film" and related materials that served instructional function for education treating. Treatment of cartoon film "Dora's film" also uses the power of teacher, word, and sound to complete attention, to help an audience understand ideas and acquire information to complex for verbal explanation, alone and to help overcame. The limitation of time, size, and space, the researchers conducted treatment in classroom. The treatment, which is used here, is using audio visual media especially cartoon film "Dora's film". This study uses a LCD Projector to show the picture and use an active speaker to make sound louder. The class was treated pre-test, treatment by using audio visual especially cartoon film "Dora's film" as media to teach vocabulary, and post-test.

c) Post Test

To get the data, a post test was given to the post test group because the design of this study is one group pre test and post test. It was given in order to know the scores of the students after they were taught by using audio visual especially cartoon film "Dora's film" as media. The respondents were asked to do the twenty five question of vocabulary. Time allocation of test is 60 minutes. This kinds of test is ten multiple choices, ten matching pictures, five coloring the pictures. In order to get the valid data, the researchers conducted: 1) Face validity: a try out was valid in term of face validity because with superficial inspection of the test format. This test was an English test for the fourth grade in MI Al Hidayah 02 Betak. The validity of test is important, a test has good validity if most of the testee will be motivated to try harder and do the test as the result the test seems to be effective; 2) Content validity is a kind of validity which depends on careful analysis of the language being tested and particular test. Trying out test of this study had content validity because the items taken were from the fourth grade students.3) Reliability: reliability is a necessary characteristic of any good test for it to be valid at all and a test must be reliable as measuring instruments. A test was given for 25 students to know the reliability of test. The reliable of whole test can be estimated by using formula (Sumarna, 2004). KR-20: $\mathrm{r}_{11}=\frac{k}{k-1}\left(\frac{S^{2}-\sum p q}{S^{2}}\right)$

Where:

$\mathrm{r}_{11}=$ Reliability using equality KR-20 
$\mathrm{p}=$ proportion of correct answer for an item

$\mathrm{q}=$ proportion of incorrect answer for an item $(\mathrm{q}=1-\mathrm{p})$

$\sum \mathrm{pq}=$ total multiplication between $\mathrm{p}$ and $\mathrm{q}$

$\mathrm{k}=$ total of question

$\mathrm{S}=$ standart deviation

$\mathrm{N}=$ amount of the students

$\sum x^{2}=$ Number of Deviation Square

The result of Reliability can be seen in Appedix IV

In experimental design, the technique analysis data that is experimental group and control group pre test post test design. It means that it has two variables investigated in this research are cartoon film media and vocabulary mastery two know there are different before and after being taught by using cartoon film media. The collected data is analyzed by using quantitative data analysis.

Quantitative data analyzing is also called statistical analysis. Usually the data classified into numerical form. In the experimental research by using pre test and post test one group designs, the data are analyzed by using the following formulation of t-test (Arikunto, 2006:86)

$$
\mathrm{t}=\frac{M d}{\sqrt{\frac{\sum x^{2} d}{N(N-I)}}}
$$

Notes :

Md = means of differential pre test and post test

$\mathrm{Xd} \quad=$ deviation in every subject $(\mathrm{d}-\mathrm{Md})$

$\sum x^{2} d \quad=$ Total of quadrate deviation

$\mathrm{N} \quad=$ Subject of sample

d.b $\quad=$ Decided by $\mathrm{N}-1$

The formula above is used to count the effectiveness of treatment.

\section{FINDINGS AND DISCUSSION}

The finding shows the students score before they were taught by using cartoon film, the students' score after they were taught by using cartoon film and the statistical test result as follows.

The result of the test about the students' achievement before and after using audio visual media especially cartoon film and percentage score in pre-test and post-test will be presented as follows:

The result of test before using Audio Visual Media especially Doras' film

Table 2 The Result of the Test before Using Audio Visual Media as Media of One Group Experimental 
The Effectiveness of Teaching Vocabulary

\begin{tabular}{|l|l|}
\hline Subject & Score of pre-test $(\mathrm{x})$ \\
\hline 1 & 84 \\
\hline 2 & 53 \\
\hline 3 & 87 \\
\hline 4 & 71 \\
\hline 5 & 73 \\
\hline 6 & 88 \\
\hline 7 & 80 \\
\hline 8 & 67 \\
\hline 9 & 68 \\
\hline 10 & 88 \\
\hline 11 & 88 \\
\hline 12 & 88 \\
\hline 13 & 88 \\
\hline 14 & 80 \\
\hline 15 & 86 \\
\hline 16 & 84 \\
\hline 17 & 87 \\
\hline 18 & 62 \\
\hline 19 & 51 \\
\hline 20 & 86 \\
\hline 21 & 57 \\
\hline 22 & 88 \\
\hline 23 & 88 \\
\hline 24 & 22 \\
\hline 25 & 65 \\
\hline & $\sum X=1879$ \\
\hline & \\
\hline
\end{tabular}

The number of the item test given were 25 questions, 10 multiple choices and 10 items arrange the sentences into good order and 5 items as matching the picture for 25 students. The pre-test had been done before treatment process (teaching vocabulary by using audio visual media cartoon film). This test is given to know the basic competence for all students and to know their earlier knowledge before they get treatment. The table shows the mean of pre-test by dividing all of score in pre-test with students number of class. So, the average of pre-test score is $\bar{X}=\frac{\sum X}{N}=\frac{1879}{25}=75.16$

The result of test after using Audio Visual Media especially Doras' film

Table 3 The Result of Test after Using Audio Visual Media as Media of One Group Experimental 
The Effectiveness of Teaching Vocabulary

\begin{tabular}{|c|c|}
\hline Subject & Score of post-test (x) \\
\hline 1 & 95 \\
\hline 2 & 75 \\
\hline 3 & 97 \\
\hline 4 & 84 \\
\hline 5 & 95 \\
\hline 6 & 91 \\
\hline 7 & 86 \\
\hline 8 & 72 \\
\hline 9 & 77 \\
\hline 10 & 95 \\
\hline 11 & 97 \\
\hline 12 & 93 \\
\hline 13 & 95 \\
\hline 14 & 95 \\
\hline 15 & 95 \\
\hline 16 & 88 \\
\hline 17 & 97 \\
\hline 18 & 73 \\
\hline 19 & 64 \\
\hline 20 & 95 \\
\hline 21 & 88 \\
\hline 22 & 95 \\
\hline 23 & 97 \\
\hline 24 & 86 \\
\hline \multirow[t]{2}{*}{25} & 73 \\
\hline & $\sum X=2198$ \\
\hline
\end{tabular}

The number of the item test given were 25 questions, 10 multiple choices, 10 matching the picture and 5 coloring the picture for 25 students. The post-test had been done after treatment process (teaching vocabulary by using audio visual media cartoon film). These tests are given to know the students' competence after they were taught by using audio visual media cartoon film, and to know their earlier knowledge after they get treatment. The table shows the mean of post-test by dividing all of scores in post-test with the students' number of class. So, the average of post-test score is :

$$
\bar{X}=\frac{\sum X}{N}=\frac{2198}{25}=87.92
$$




\subsection{Statistical Test Result}

It is conducted statistical test using t-test formula to guarantee the effectiveness of audio visual media on students' vocabulary achievement of MI Al Hidayah 02 Betak. The test results are as follows:

Table 4 The statistical result using $\mathrm{t}_{\text {- }}$ test of pre-test and post-test one group design

\begin{tabular}{|c|c|c|c|c|c|c|}
\hline $\begin{array}{l}\text { Respondent } \\
\text { No }\end{array}$ & $\begin{array}{l}\text { Pre- } \\
\text { Test } \\
\text { Score }\end{array}$ & $\begin{array}{l}\text { Post- } \\
\text { Test } \\
\text { Score }\end{array}$ & $\begin{array}{l}\text { Gain (d) } \\
\text { (Post-test } \\
\text { Pre-Test) }\end{array}$ & $d^{2}$ & $\begin{array}{l}\mathrm{Xd} \\
(\mathrm{d}-\mathrm{Md})\end{array}$ & $X^{2} d$ \\
\hline 1 & 84 & 95 & 11 & 121 & $-1,67$ & 2,79 \\
\hline 2 & 53 & 75 & 22 & 484 & 9,33 & 85,37 \\
\hline 3 & 87 & 97 & 10 & 100 & $-2,76$ & 7,62 \\
\hline 4 & 71 & 84 & 13 & 169 & 0,24 & 0,06 \\
\hline 5 & 73 & 95 & 22 & 484 & 9,24 & 85,37 \\
\hline 6 & 88 & 91 & 3 & 9 & $-9,76$ & 95,26 \\
\hline 7 & 80 & 86 & 6 & 36 & $-6,76$ & 45,69 \\
\hline 8 & 67 & 72 & 5 & 25 & $-7,76$ & 60,22 \\
\hline 9 & 68 & 77 & 9 & 81 & $-3,76$ & 14,14 \\
\hline 10 & 88 & 95 & 7 & 49 & $-5,76$ & 33,18 \\
\hline 11 & 88 & 97 & 9 & 81 & $-3,76$ & 14,14 \\
\hline 12 & 88 & 93 & 5 & 25 & $-7,76$ & 60,22 \\
\hline 13 & 88 & 95 & 7 & 49 & $-5,76$ & 33,18 \\
\hline 14 & 80 & 95 & 15 & 225 & 2,24 & 5,02 \\
\hline 15 & 86 & 95 & 9 & 81 & $-3,76$ & 14,14 \\
\hline 16 & 84 & 88 & 4 & 16 & $-8,76$ & 76,74 \\
\hline 17 & 87 & 97 & 10 & 100 & $-2,76$ & 7,62 \\
\hline 18 & 62 & 73 & 11 & 121 & $-1,67$ & 2,79 \\
\hline 19 & 51 & 64 & 13 & 169 & 0,24 & 0,06 \\
\hline 20 & 86 & 95 & 9 & 81 & $-3,76$ & 14,14 \\
\hline 21 & 57 & 88 & 31 & 961 & 18,24 & 332,69 \\
\hline 22 & 88 & 95 & 7 & 49 & $-5,76$ & 33,18 \\
\hline 23 & 88 & 97 & 9 & 81 & $-3,76$ & 14,14 \\
\hline 24 & 22 & 86 & 64 & 4096 & 51,24 & 2625,54 \\
\hline 25 & 65 & 73 & 8 & 64 & $-4,76$ & 22,66 \\
\hline $\mathrm{N}=25$ & $\begin{array}{l}\sum=187 \\
9 \\
\overline{X_{1}}= \\
75,16\end{array}$ & $\begin{array}{l}\sum_{8}=219 \\
\overline{X_{2}}= \\
87,92\end{array}$ & $\sum_{319} d=$ & $\sum_{76} \mathrm{~d}^{2}=101$ & & $\begin{array}{l}\sum_{3600,59} X^{2} d= \\
\text { S }\end{array}$ \\
\hline
\end{tabular}

$\mathrm{Md}=\frac{\sum d}{N}=\frac{319}{25}=12,76$ 


$$
\begin{aligned}
& \mathrm{t}=\frac{M d}{\sqrt{\frac{\sum X^{2} d}{N(N-1)}}}=\frac{12,76}{\sqrt{\frac{3600,59}{25(25-1)}}}=\frac{12,76}{\sqrt{\frac{3600,59}{600}}}=\frac{12,76}{\sqrt{6,001}}=\frac{12,76}{2,45}=5,20 \\
& \mathrm{t}_{\text {count }}=5,20 \\
& \text { After get the result of } \mathrm{t}_{\text {count }}, \text { so } \mathrm{t}_{\text {count }} \text { is consulted to } \mathrm{t}_{\text {table }} \\
& \mathrm{d} \cdot \mathrm{b}=\mathrm{N}-1=25-1=24 \\
& \text { it is found } \mathrm{t}_{\text {table }} \text { for } \mathrm{t}_{0,05}=1,71
\end{aligned}
$$

The result of the-test was 5,20. It was consulted the critical value on the ttable using the $5 \%(0,05)$ alpha level of significance and the 24 degree of freedom which was 1,71 . Since the obtained t-value was higher than the critical value on the table $(5,20>1,71)$, the difference was statistically significant. Seeing the result of the pre test \&post test, so the null hypothesis is rejected. It means that there were any significant different between score of pretest and posttest.

\subsection{Hypothesis Testing}

The hypothesis of this study can be alternative and null hypothesis. The hypothesis is as follows:

1. If T-Test score is higher than T-Table, the alternative hypothesis (Ha) is accepted. From the data analysis shows that $t_{\text {count }}>t_{\text {table }}(5,20>1,71)$, so $\mathrm{Ha}$ is accepted. It means that there is different score to the first grade before using cartoon film and after using cartoon film. The different is significant; it means that using cartoon film to teach English vocabulary is accepted.

2. If T-test score is similar than T-table, the null hypothesis (Ho) is rejected. From the data analysis shows that $\mathrm{T}_{\text {table }}<\mathrm{T}_{\text {count }}(1,71<5,20)$. It means that there is different score to the fourth grade before using cartoon film and after using cartoon film. So the $\mathrm{H} 0$ is rejected.

\section{DISCUSSION}

From the data analysis, the objective of this study was to know if there was an effect of using audio visual cartoon film as media in teaching vocabulary to the vocabulary mastery achieved by the EFL students of MI AL Hidayah 02 Betak Tulungagung. The use of audio visual media cartoon film will significant if $t_{\text {count }}>t_{\text {table }}$. Data analysis above shows that $t_{\text {count }}>t_{\text {table }}(5,20>1,71)$, so $\mathrm{Ho}$ is rejected or $\mathrm{Ha}$ is accepted.. In the pre-test, the average score $1879\left(\bar{X}_{1}\right.$ $=75,16)$, while in the post-test the average score was $2198\left(\bar{X}_{2}=87,92\right)$. Although it shows difference between the two means, the result shows that the post-test was better than the pre-test. According to the convention of level of achievement, the result of teaching vocabulary by using audio visual (cartoon film) media was enough and the average score was $2198\left(\bar{X}_{2}=87,92\right)$. To check 
the significant effect of the treatment, it was analyzed by using t-test formula. The result of the t-test was 5,20. It was consulted the critical value on the t-table using the $5 \%(0,05)$ alpha level of significance and the 24 degree of freedom which was 1,71.Since the obtained t-value was higher than the critical value on the table $(5,20>1,71)$, the difference was statistically significant. The result is rejecting the null hypothesis. It means that there were any significant different between score of pre-test and post-test. It can be concluded that the students get good achievement in mastering vocabulary after taught by using audio visual media (cartoon film).

The students' vocabulary mastery improve significantly, so teaching vocabulary by using audio visual media (cartoon film) is effective to improve students' mastery on vocabulary. This finding is similar like the findings of Juriah (2015) who studies the implementation of controlled composition to improve vocabulary mastery of EFL students.

\section{CONCLUSION}

Based on the result of the study, it can be concluded that: 1) The students' score before being taught by using audio visual media (cartoon film). The result of pre-test was achieved, there are 15 students who get excellent result, there are 2 students who get good, there are 4 students who get fair result, there are 3 students who get poor result and 1 student who gets very poor result. Those are the students' score before being taught using audio visual media especially cartoon film. 2) The students' score vocabulary after being taught by using audio visual media (cartoon film). The result of post-test achieved, there are 19 students who get excellent result, there are 5 students who get good result and there is 1 student who gets fair result. Those are the students score after using audio visual media (cartoon film). 3) The significant difference between students' score before and after being taught by using audio visual media (cartoon film). The result of pre test showed that 15 students who get score 80100. The result of post-test showed that 19 students who get score $80-100$. The result of this research also showed that $t_{\text {count }}>t_{\text {table }}(5,20>1,71)$. It means that there were any significant influences between score of pre-test and post-test. It can be concluded that the students get good achievement in mastering vocabulary after taught by using audio visual media (cartoon flm). It means that teaching vocabulary by using cartoon film media is effective to improve students' mastery on vocabulary. Audio visual media (cartoon film) is effective to teach English, especially vocabulary, so it can be one of reference media to teach English.

Based on the research finding, some suggestions are given to head master, English teacher, students and the next research are as follows: 1) The head master should give enough facilities, so teaching and learning English will work well such as LCD projector. Audio visual media will make easier the teacher to teach and help the students to understand. Hopefully, the students get good achievement by using media especially audio visual media.2)English teacher should use various audio visual media especially cartoon film, so that the 
students will not get bored during the teaching and learning process;3)For other researchers could use this study as their milestone to conduct other research on the different dimensions. They may use true experimental research design to know whether the method more effective or not.

\section{REFERENCES}

Arsyad, Azhar. (2008). Media Pembelajaran, Jakarta : PT. Rajagrafindo Persada. Ary, Donald. (1985). Introduction to Research in Education, $3^{\text {rd }}$ edition, Northern Illinois University.

Daryanto. (2010). Media Pembelajaran, Yogyakarta : Gava Media. Djamarah, Syaiful Bahri \& Zain, Aswan, Strategi belajar mengajar, Jakarta : PT.Rineka Cipta.

Djiwandono, M. Soenardi. (1996). Tes Bahasa dalam Pengajaran, Bandung : ITB.

Djiwandono, S.Patrisius Istiaro. (2009). Strategi Belajar Bahasa Inggris, Indonesia : PT Malta Pritindo.

Harmer, Jeremy. (1991). The Practice English Language Teaching, Longman Group: UK..

Harris, David P. (1969) Testing English as a second Language, New York : Mc. Graw - Hill, Inc.

Iftanti, Erna. (2015). Investigating Inspiring English Lecturers in a Faith-Based Educational Institution: EFL Learners' Perception. Dinamika Ilmu, Vol. 15 No. 2, 2015

Juriah, J. (2015). Implementing Controlled Composition to Improve Vocabulary Mastery of EFL Students. Dinamika Ilmu, Vol. 15 No. 1, 2015

Nunan, David. (1991).Language Teaching Methodology, New York : Prentice Hall International (UK) Ltd.

Nurhayati, Dwi Astuti Wahyu. (2008a). Improving Students'English Vocabulary Mastery through Games (A Classroom Action Research in the Islam Kindergarten of Al-Irsyad Madiun in the Academic Year 2007/2008). Surakarta.Graduate School of Sebelas Maret University.

Nurhayati, Dwi Astuti Wahyu. (2014b). Using Picture Series to Inspire Reading Comprehension for the Second Semester Students of English Department of IAIN Tulungagung. Dinamika Ilmu Journal.Vol.14.No.2.Desember 2014: 176-189.

Nurhayati, Dwi Astuti Wahyu. (2015a). Improving Students' English Pronunciation Ability through Go Fish Game and Maze Game. Dinamika Ilmu Journal.Vol 15 No 2, December 2015: 215-234.

Putranti, Sulistini Dwi \& Mina, Nurawati. (2015). Designing Cartoon as a Supplementary English Material for English Structure Subject. Dinamika Ilmu, Vol. 15 No 1, 2015 
Redman, Stuart. (2002). English Vocabulary In Use-Pre-Intermediate and Intermediate, Jakarta : PT Gelora Aksara Pratama. Richards, Jack C., \& Renandya, Willy A. (2002). Methodology in Language Teaching : An Anthology of Current Practice, USA : Cambridge University Press.

Sadiman, S.Arif. (1986). Media Pendidikan, Jakarta : Rajawali..

Setiyadi, Bambang. (2006).Teaching English As A Foreign Language, Yogyakarta : Graha Ilmu,.

Smaldino, E.Sharon, et al. (2002). Instructional Technology and Media for Learning, USA: Pearson.

Sumadi, Suryabrata. (2010). Metodologi Penelitian, Jakarta : Rajawali Press.

Surapranata, Sumarna. (2004). Analysis, Validity, Reliability dan Interpretasi Hasil Tes, Jakarta:Rosda.

Widodo, Supriono. (2005). Akhlak Tasawwuf. Bandung: Penerbit Nuansa.

Http://michiana.ja.org/Local_Eleme,html. Retrieved on January 2010.

Http://wyw1d.wordpress.com/2010/01/15/film-kartun-sebagaimediapembelajaran/.retrieved on January 2010. 